Певну частину учителів можна віднести до категорії невідповідності методичної грамотності з причини хибності та некоректності відповідей на питання анкети, пов'язаних з методикою проведення уроків.

\title{
Література
}

1. Аксьонова О. П. Нова фізична культура: система методів навчання / О. П. Аксьонова // Теорія та методика фізичного виховання. - 2011. - №3. - С. 25-31. 2. Марченко С. І. Оцінка фізичного розвитку хлопців 6-10 років у контексті сучасних завдань фізичного виховання / С. І. Марченко, В.В.Іванов // Теорія та методика фізичного виховання. - 2011. - № 8. - С. 10-13. 3. Пелешко І. М. Показники фізичного розвитку та фізичної підготовленості учнів 1 класів загальноосвітніх навчальних закладів / І. М. Пелешко // Педагогіка, психологія та медико-біологічні проблеми фізичного виховання i спорту: зб.наук.пр./за ред. Срмакова С.С. Х. :ХДАДМ, 2013. - №8. - С. 65-68. 4. Ткачук С. В. Характеристики рухової активності хлопчиків і дівчат молодшого шкільного віку в умовах мегаполісу/ С. В. Ткачук, О. В. Давиденко // Науковий часопис Національного педагогічного університету ім. М. П. Драгоманова. Серія№15 «Науково-педагогічні проблеми фізичної культури / Фізична культура і спорт» / За ред. Г. М. Артюзова. - К. : Вид-во НПУ ім. М. П. Драгоманова, 2013.Том 2 - Випуск 7. - С. 306-311. 5. Франків Є. Є. Позашкільна діяльність учнів середнього шкільного віку та іiі вплив на здоров'я/ Є. Є. Франків // Науковий часопис Національного педагогічного університету ім. М. П. Драгоманова. Серія №15 «Науково-педагогічні проблеми фізичної культури /Фізична культура і спорт»/ За ред. Г. М. Артюзова. - К. : Вид-во НПУ ім. М. П. Драгоманова, 2013. - Том 2 - Випуск 7. - С. 363-368.

Вікторія Яковлєва

\section{СУКУПНІСТЬ КОМПОНЕНТІВ САМОСТІЙНОЇ ЖИТТЕДІЯЛЬНОСТІ ВИПУСКНИКІВ ШКІЛ-ІНТЕРНАТІВ ЯК ОСНОВА ФОРМУВАННЯ ЇХ ЖИТТЕВОЇ КОМПЕТЕНТНОСТІ}

Яковлєва В. А. Сукупність компонентів самостійної життєдіяльності випускників шкіл-інтернатів як основа формування їх життєвої компетентності.

У статті розкривається сутність та зміст життєвої компетентності та самостійної життєдіяльності особистості, характеризуються основні компоненти самостійної життєдіяльності випускників шкіл-інтернатів, аналізується низка типових соціальних моделей їх поведінки та процес оволодіння соціальним досвідом для успішної реалізації в соціумі різних соціальних ролей з опорою на внутрішні ресурси, розглядається процес формування життєвої компетентності названого контингенту як сукупність компонентів самостійної життєдіяльності.

Ключові слова: життєдіяльність, самостійна життєдіяльність, життєва компетентність, випускники шкіл-інтернатів, соціальний досвід.

Яковлева В. А. Совокупность компонентов самостоятельной жизнедеятельности выпускников школ-интернатов как основа формирования их жизненной компетентности.

В статье раскрывается сущность и содержание жизненной компетентности и самостоятельной жизнедеятельности личности, характеризуются основные компоненты самостоятельной жизнедеятельности выпускников школ-интернатов, анализируется ряд типичных социальных моделей их поведения и процесс освоения социальным опытом, с целью успешной реализации в социуме различных 
социальных ролей с опорой на внутренние ресурсы, рассматривается процесс формирования жизненной компетентности даного контингента как совместность компонентов самостоятельной жизнедеятельности

Ключевые слова: жизнедеятельность, самостоятельная жизнедеятельность, жизненная компетентность, выпускники школ-интернатов, социальный опыт.

Yakovleva V. A. The set of independent components of life graduates of boarding schools as a basis for shaping their life competence.

The article reveals the gist and contents of vital competence and self- life personality, by the basic components of an independent life of graduates of boarding schools, examines a number of typical patterns of social behavior and social process of learning experiences, with a view to the successful implementation of the society in different social roles, drawing on internal resources, the process of formation of vital competence contingent as joint components independent life.

Key words: livelihoods, independent livelihoods, life competence, graduates of boarding schools, social experience.

Самостійна життєдіяльність сучасної людини складається 3 того соціокультурного середовища, яке вона створює, де реалізуються іiі потреби, можливості та інтереси з опорою на значущі для неї цінності.

Вихованці інтернатних закладів унаслідок закритого характеру виховання, його змісту i методів, зумовлених цим явищем, своїх психофізіологічних особливостей не набувають того соціального досвіду, який гарантував би їм успішну самореалізацію в соціумі після випуску 3 інтернатного закладу. Невідповідність умов життєдіяльності в інтернатному закладі та після випуску 3 нього призводить до того, що вихованці виявляються непідготовленими до самостійного життя в соціумі. При цьому виокремлюється низка типових соціальних моделей поведінки, зокрема:

1) об'єднання підлітків в одній квартирі для мешкання і здача звільненої кімнати в оренду;

2) після закінчення першого ПТУ замість роботи йдуть «вчитися» в друге, хоча заняття не відвідують і перебувають на повному державному забезпеченні;

3) замість влаштування на роботу звертаються на біржу праці, де виплати 3 безробіття істотно вищі, ніж можливий заробіток [3].

Отже, замість вияву активної економічної позиції, багато випускників намагаються отримати максимум того, що може дати статус «сироти» або «залишився без піклування батьків». Фахівці органів опіки та піклування говорять про те, що часто при зверненні до них випускники запитують: «А що я ще можу безкоштовно отримати?» За наявності роботи вони легко ii втрачають; отримавши житло, позбавляються кімнати, квартири в результаті безглуздих угод або приводять їх у непридатність, не хочуть і не можуть навчатися, вступивши до вищого навчального закладу; кидають своїх дітей у пологових будинках тощо.

За всіма критеріями соціальної роботи основна маса випускників знаходиться в ситуації соціальної депривації. Складається парадоксальна ситуація: з одного боку, на забезпечення соціального захисту вихованців шкіл-інтернатів витрачаються достатні ресурси, до роботи залучається велика кількість фахівців, а ефективність усіх зусиль непропорційно мала: вихованець виявляється незахищеним після випуску 3 інтернатних установ, не в змозі повноцінно адаптуватися в суспільстві i жити самостійно. Факти свідчать, що близько 40\% випускників інтернатних установ 
потрапляють в криміногенні структури, майже $40 \%$ стають наркоманами й алкоголіками, 10\% закінчують життя самогубством і лише $10 \%$ якось виживають [3].

Статистичні показники по дитячих будинках Дніпропетровської області з 2005 року по 2012pр. показують:

- тенденцію збільшення кількості дітей в дитячих установах, що пояснюється зростанням соціального сирітства в Дніпропетровській області;

- збільшення кількості випускників дитячих установ з освітою менше дев'яти класів і з освітою 9 класів;

- тенденція зниження рівня освіченості - більше, ніж у 10 разів збільшилася кількість випускників, які отримали освіту менше дев'яти класів, майже в три рази знизилася кількість випускників, які мають освіту одинадцять класів, практично всі випускники навчаються в ПТУ, у ВНЗ вступають одиниці, зниження кількості вихованців дитячих будинків, які отримують повну загальну освіту у школі;

- тенденцію зростання отримання професійної освіти у професійних навчальних закладах початкового і середнього рівня, що пояснюється формальною передачею вихованців у спеціалізовані професійні заклади для дітей-сиріт; незначна кількість випускників дитячих будинків Дніпропетровської області, які вступають у вищі навчальні заклади, що свідчить про недоступність вищої освіти для цієї категорії дітей, а також про відсутність у них знань про свої права, відсутності поведінкових навичок в реалізації своїх прав, відсутність у них настанов пріоритетності вищої освіти.

Наприклад, у 2011 році $з$ дитячих будинків Дніпропетровської області було випущено 198 вихованців, із яких повну загальну освіту отримали тільки 2 людини, 124 вихованці отримали неповну загальну освіту, 72 вихованці випущені без базової освіти. До ВНЗ вступила тільки одна особа, продовжили освіту в 10 класі - 6 осіб, у технікуми Дніпропетровської області вступили 2 особи, в педагогічне училище - 3 особи, в медичне училище - 1 особа, у школу міліції- 1 особа. В училища м. Кривого Рогу вступили 7 осіб, в училища м. Дніпродзержинська -4 особи, м. Нікополя 3 особи, м. Марганця - 4 особи, м. Дніпропетровська - 5 осіб тощо. Основні спеціальності, які обрали для себе вихованці шкіл-інтернатів у 2011-2012 роках: господиня садиби, городник, кухар, кухар-кондитер - 36 осіб, тракторист, автомеханік, водій, - 19 осіб, слюсар-ремонтник- 45 осіб, маляр-штукатур, будівельник, плиточник - 12 осіб, зварник -7 осіб, бухгалтер - 6 осіб, швачки - 6 осіб. Низький рівень адаптації випускників інтернатних установ у соціумі пояснюється несформованістю їх життєвої компетентності, зумовленої умовами життя в інтернатних установах, психофізіологічними особливостями вихованців, мізерним соціальним досвідом.

Тому виникає необхідність розглянути процес формування життєвої компетентності випускників інтернатних закладів як сукупність компонентів їх самостійної життєдіяльності.

Задля розуміння суті та змісту самостійної життєдіяльності уважаємо за необхідне розглянути у психологічному аспекті поняття «життєдіяльність», «життєва компетентність» тощо.

Проблеми, пов'язані 3 життям особистості, вивчали такі дослідники, як: К. Абульханова-Славська [1], Б. Ананьєв [2], П. Підкасистий [4] та інші.

Б. Ананьєв зазначав, що процес пристосування до навколишнього світу не $\epsilon$ пасивним, не зводиться до абсолютного «обтисування» організму середовищем, але сам діє на своє оточення відповідно до власної, простої або складної структури. Ці зміни, зроблені ним у середовищі, позначаються на організмі і його діяльності [2]. 
П. Підкасистий подає визначення самостійної життєдіяльності в глобальному вигляді як системи, що містить такі компоненти:

- змістовний - знання, що виражаються в поняттях, образах і уявленнях;

- оперативний - різноманітні дії, оперування вміннями, прийомами як у зовнішньому, так і у внутрішньому плані дій;

- результативний - нові знання, способи вирішення; новий соціальний досвід, ідеї, погляди, здібності та якості особистості [4, с. 55].

Аналізуючи роботи дослідників життєвої компетентності, П. Підкасистий зазначає, що життєва компетентність виявляється у всьому різноманітті ставлення особистості до навколишнього світу і є складником структури практично всіх видів конкретної діяльностей. «У процесі формування життєвої компетентності особистість не тільки засвоює і привласнює об'єкти природного і суспільного середовища, розкриваючи для себе їх суспільний зміст і призначення, а й перетворює, у певному сенсі створює своє соціальне середовище, ґопредмечує свої суттєві сили», реалізуючи творчі сили розуму» [4, с. 52].

За характером отриманого в процесі діяльності продукту П. Підкасистий умовно розділив всі конкретні діяльності, що мають соціальне значення, на теоретичні i практичні. «Теоретична діяльність генетично бере початок у практичній, і продукти їі - знання в кінцевому результаті знову-таки включаються у практичну діяльність. Практична діяльність, використовуючи як інструменти (знаряддя-засоби) продукти теоретичної діяльності, на цій основі постійно і неухильно ускладнюється і вдосконалюється, висуваючи до людини все більш складні та відповідальні вимоги» [4, с. 5].

Метою статті є обгрунтування процесу формування життєвої компетентності випускників інтернатних закладів як сукупності компонентів їх самостійної життєдіяльності.

Досягнення педагогічних цілей через отримання особистого досвіду в різних галузях діяльності, розглянутих вище, на нашу думку, здійснюється за допомогою системи формування життєвої компетентності кожної людини. Відмінною рисою процесу формування життєвої компетентності є наявність єдності двох протилежних процесів: засвоєння соціального досвіду індивідом i його примноження, яке відбувається у процесі активної творчої діяльності.

Життєва компетентність виявляєтья в будь-якому особистості до навколишнього світу: у виробничо-економічній, науково-пізнавальній, художньоестетичній, суспільно-політичній, сімейній, ігровій, спортивній, навчальній та інших видах діяльності і спрямована на перетворення суспільних відносин за допомогою виробництва деяких матеріальних чи духовних цінностей.

Для свого дослідження ми приймаємо твердження, що життєва компетентність формується через освоєння видів діяльності різного характеру, які служать умовою і засобами для кожного індивіда.

Для здійснення повноцінної самостійної життєдіяльності в соціумі, після виходу з інтернатного закладу вихованцям необхідно оволодіти різними видами діяльності в різних сферах, де для них видається проблематичним виконання конкретної соціальної ролі, тобто оволодіння конкретними видами соціального досвіду.

В. Сластенін та Л. Подимова стверджують, що для реалізації активності особистості наявні великі можливості, оскільки цьому сприяє «... низка змін, що відбуваються в житті і відбиваються в мисленні людини. Головна 3 них - зняття обмежень у життєдіяльності, що дозволяє сприймати значно більше коло зовнішніх 
явищ. Зменшення упереджених і нав'язуваних думок, збільшення потоку інформації забезпечує необхідну свободу дій, своєчасне реагування на зовнішні зміни. У результаті, розвиваються важливі здібності - готовність до прийняття самостійних рішень, критичність, готовність нести відповідальність, креативність» [6, с. 32].

Одночасно відбувається становлення і розвиток самостійності- особистісної властивості індивіда, що припускає, «по-перше, незалежність суджень і дій, здатність самому, без сторонньої допомоги і підказки, реалізовувати важливі рішення, по-друге,- відповідальність за свої вчинки та їх наслідки, по-третє, внутрішню впевненість у тому, що така поведінка можлива і правильна» [6, с. 19].

Також необхідно зауважити, що для формування життєвої компетентності вихованців інтернатних закладів, необхідним $\epsilon$ вироблення в них соціального досвіду, що дозволяє розв'язувати їм особистісно значущі проблеми в самостійній життєдіяльності.

У світлі цього твердження визначимо життєву компетентність як сукупність компонентів самостійної життєдіяльності, використовуючи систему формування професійної компетентності, яка передбачає: аксіологічний, мотиваційноцілепокладаючий, когнітивний, операційний, аналітико-рефлексивний та індивідуально-творчий компоненти.

Аксіологічний компонент полягає в усвідомленні дитиною значущості повноцінного самостійного життя в соціумі, усвідомлення цінності необхідних життєвих знань, визнання пріоритетності особистісної реалізації в дорослому житті.

Мотиваційно-цілепокладаючий компонент передбачає готовність і інтерес вихованця до повноцінного життя в суспільстві, визначення й усвідомлення цілей у самостійному житті, наявність мотивів досягнення цілей.

Когнітивний компонент відображає наявність необхідного мінімуму знань, умінь, навичок і здатності застосовувати їх у нових умовах; вміння класифікувати і систематизувати життєві явища; вміння виокремлювати життєві проблеми, аналізувати, оцінювати і приймати рішення.

Операційний компонент полягає в ефективності і продуктивності діяльності під час розв'язання життєвих проблем різного характеру; в оволодінні практичними вміннями та навичками для розв'язання життєвих проблем; у самостійному оволодінні новими методами і способами розв'язання нових життєвих проблем в умовах, що змінилися; у плануванні власного подальшого самостійного життя за межами інтернатного закладу; у реалізації планів, можливих в межах інтернатного закладу, що впливають на подальшу життєдіяльність вихованця.

Аналітично-рефлексивний компонент передбачає оволодіння аналітичними й оціночно-інформаційними знаннями; рефлексія, самокритичність вихованця інтернатного закладу; самоконтроль, самооцінка.

Індивідуально-творчий компонент відображає гнучкість i варіативність мислення, усвідомлення наявності у себе здібностей для розв'язання життєвих проблем, зростаючу динаміку активності у життєдіяльності; планування свого життя та поступову реалізація життєвих планів, дослідницький підхід до будь-якої діяльності; готовність до життєвих труднощів і їх подолання.

Отже, самостійність вихованця інтернатного закладу $є$ процесом оволодіння соціальним досвідом для успішної реалізації в соціумі різних соціальних ролей 3 опорою на внутрішні ресурси. Різноманіття соціальних ролей, що реалізуються особистістю в самостійній життєдіяльності, зумовлює необхідність визначення змісту та методів виховання дітей в інтернатних закладах, які сприяли б набуттю 
ними соціального досвіду в різних сферах життєдіяльності особистості, необхідного для успішної самореалізації в соціумі.

Сукупність компонентів життєдіяльності особистості визначає групи завдань: адаптації, автономізації та активізації особистості.

Соціальна адаптація передбачає активне пристосування індивіда до умов соціального середовища. Реалізація сукупності настанов на себе, стійкість в поведінці i стосунках, яка відповідає уявленню особистості про себе, іiі самооцінка, - є автономізацією. Активізація особистості передбачає сформовану готовність особистості до соціальних дій [5, с. 13-14].

Підготовка до самостійної життєдіяльності вихованців інтернатних закладів повинна бути зорієнтована на їх майбутній батьківський потенціал, щоб життєва компетентність їхніх дітей формувалася в природних сімейних умовах, які випускники інтернатних установ зможуть забезпечити своїм дітям.

Отже, враховуючи все вищевикладене, необхідно відзначити, що: по-перше, взаємний вплив соціокультурного середовища й особистості визначає сукупність компонентів життєдіяльності особистості, якими необхідно їй володіти для успішної самореалізації в соціумі; по-друге, життєва компетентність вихованця інтернатного закладу, як сукупність компонентів його життєдіяльності зумовлює розв'язання типових проблем у дорослому житті; по-третє, формування життєвої компетентності вихованців інтернатних закладів зумовлює необхідність організації цілеспрямованої навчально-виховної роботи, спрямованої на отримання вихованцями соціального досвіду задля їх підготовки до самостійного життя.

\section{Література}

1. Абульханова-Славская К. А. Стратегия жизни / Ксения Александровна Абульханова-Славская. - М. : Мысль, 1991. - 299 с. 2. Ананьев Б. Г. Человек как предмет познания / Борис Герасимович Ананьев // Избранные психологические труды: в 2 т. Т. 1 / Под ред. А. А. Бодалева, Б. Ф. Ломова. - М. : Педагогика, 1980. С. 16-178. 3. Кундозерова Л. И. Состояние проблемы социальной защиты воспитанников интерната в практике образования/ [Электронный ресурс]/ Людмила Ивановна Кундорова.www.informika.ru/text/magaz/pedagog/ pedagog/a23.html. 4. Подкасистый П. И. Самостоятельная познавательная деятельность школьников в обучении / Павел Иванович Подкасистый. - М. : Педагогика, 1980. - 240 с. 5. Прихожан А. М. Подросток в учебнике и в жизни / А. М. Прихожан, П. Н. Толстых. - М. : Знание, 1990. - 79 с. 6. Сластенин В. А. Педагогика: инновационная деятельность/ В. А. Сластенин, Л. С. Подымова. - М. : ИЧП Магистр, 1997. - 224 с. 